\title{
Bigámia nászajándékba: Samuel Spillenberger nászéneke Máriássy János és Palugyay Zsófia esküvőjére (1635)
}

\begin{abstract}
The present article discusses a set of poems registered in print nr. 1620 of the Régi Magyarországi Nyomtatványok catalogue. The poem was dedicated by a doctor of medicine from Levoča, Samuel Spillenberger to his alleged godson, the nobleman János Máriássy. Spillenberger wrote three poems in the name of each married brothers of Máriássy. The second poem, allegedly sang by Máriássy's youngest brother, András, tells a story about a bigamist crusader from the $12^{\text {th }}$ century. After presenting the family backgrounds of both the author and the addressees, the paper sheds light on the origin and possible sources of the story. Pointing out some specific textual properties of Spillenberger's poem, the paper tries to trace down its exact source. It also offers a panoramic picture about the presence of the bigamist figure in German neo-Latin Literature and culture from the $16^{\text {th }}$ to the $19^{\text {th }}$ century. Finally, the article closes with some remarks about the position of the poem in its own literary context of seventeenth-century neo-Latin wedding poetry in Hungary. ${ }^{1}$
\end{abstract}

Az alkalmi versszerzés központjai a XVII. század folyamán FelsőMagyarország és Erdély fejlett gazdasággal és müvelt értelmiségi réteggel rendelkező városai voltak. A külföldi egyetemet járt, általában német ajkú és lutheránus vallású alkalmi költők többsége prédikátori vagy tanítói tisztséget töltött be, de számosan voltak köztük jogászok, orvosok és gyógyszerészek is, ahogy erről a Régi Magyarországi Nyomtatványok (RMNY) köteteiben olvasható részletes bibliográfiai leírások tanúskodnak. A jelen tanulmány tárgya egy tudós orvos, a lőcsei Samuel Spillenberger (1573-1654) lakodalmi költeményeinek egyike, amelyet a

\footnotetext{
${ }^{1}$ A publikáció az MTA-SZTE Antikvitás és Reneszánsz: Források és Recepció Kutatócsoport (TK2016-126) támogatásával jelent meg.
} 
szöveg tanúsága szerint keresztfia, márkusfalvi Máriássy János és Palugyay Zsófia 1635. január 14-én tartott esküvőjére írt. A szóban forgó mü az RMNY 1620 számon nyilvántartott gyüjteményének utolsó darabja, ${ }^{2}$ amelynek címe Carmen joco-serium polymetron. Pro exhilarandis dominis hospitibus nuptiarum Generosi Domini Ioannis Mariasi de Markusfalva Sponsi etc. A költemény elsősorban témája miatt emelkedik ki az egyébként is nagy tematikus és formai változatosságot mutató magyarországi latin nyelvű nászének-költészet termékei közül, amennyiben egy rossz feleségről és egy, az első szexuális tapasztalattól félő friss asszonyról szóló történet között egy (állítólag) megtörtént esetet, a XII-XIII. század fordulóján élt bigámista kereszteslovag történetét meséli el a jó házasság példájaként. Dolgozatom először bemutatja a szerző és a házasulandók társadalmi hátterét, majd azt kutatja, hogy milyen forrásban olvashatta Spillenberger a történetet, végül a hazai esküvői alkalmi szerzemények mezőnyében próbálja meg elhelyezni a lőcsei orvos munkáját.

\section{Az orvos és az ifjú pár}

Samuel Spillenberger élettörténetét részletesen megírta családjának egy kései leszármazottja. ${ }^{3} \mathrm{Az}$ összegyüjtött adatokból kiemelendő, hogy több német városban folytatott tanulmányai után Spillenberger 1598-tól dolgozott orvosként Lőcsén, majd más felső-magyarországi településeken, de Erdélyben is, Bethlen Gábor fejedelem szolgálatában. Tudása révén meglehetős hírnévre, illetve pártfogókra tett szert, és 1615-ben II. Mátyás király nemességet adományozott neki. Ugyanebben az évben Spillenberger papírmalmot létesített, amely a század végéig családja tulajdonában maradt, s a nyomdákkal való üzleti kapcsolata mellett irodalmi pártfogóként támogatta különböző művek kiadását is. Samuel Spillenberger a korban szokatlanul hosszú életet, 81 évet élt, s ezalatt kétszer nősült meg. 1600 körül már a felesége volt Jonas Dirner ismeretlen nevü leánya, majd annak halála után Spillenberger 1616. április 24én feleségül vette Magdalena Clementist. ${ }^{4}$ Úgy tünik, Spillenberger mind a nyolc gyermekének ez utóbbi hölgy volt az édesanyja. Az

\footnotetext{
${ }^{2}$ CEBANI (1635).

3 SPILENBERGER-DIÓSZEGI (1999).

${ }^{4}$ RMNY 1110.
} 
RMNY tanúsága szerint Spillenberger legalább négy epithalamiumgyüjteményben szerepelt szerzőként, ${ }^{5}$ amelyek közül a MáriássyPalugyay esküvőre készült müve a második legkorábbi fennmaradt darab. Az utolsó ismert nászénekében, amelyet Joseph Schlegel és Rosina Gloger 1648. október 25-én tartott esküvőjére írt, az akkor már 75 éves Samuel Spillenberger sajnálatát fejezte ki, hogy idős korára való tekintettel ő már nem nősülhetett meg újra, és beszámolt arról is, hogy mindkét házasságát nagyon élvezte. Spillenberger talán szerelmes típus lehetett, mert életrajzírója talált egy levelet, amelynek tanúsága szerint a férfi még egyetemi hallgatóként, 1596-ban Regensburgban csaknem nősülésre adta a fejét, amiről csak családja határozott tiltakozására mondott le. ${ }^{6}$ A házassággal való jó személyes tapasztalatai miatt nem csoda, hogy Spillenberger vidám, kissé pajkos, s különösen a Máriássy-Palugyay nászének esetében a férfifantáziát megmozgató lakodalmi verseket írt.

Az ifjú pár hölgytagjáról, mint a nőkre vonatkozó történeti forrásellátottság miatt ez sajnos megszokott, alig tudunk valamit. Palugyay Zsófia nemesi származású volt, Palugyay Ferenc liptói alispán leánya. Nagy Iván családtörténete egy ellentmondásos adatot tartalmaz vele kapcsolatban, azt állítja ugyanis, hogy az 1647. és az 1649. évi országgyülés is megemlékezik Palugyay Zsófiáról, mint Máriássy János özvegyéről, s az asszonytól Révay Ferenc által elvett javakat visszaadni rendeli. ${ }^{7}$ A Corpus Juris Hungarici vonatkozó helyei azonban nem özvegynek, hanem Máriássy János hitvestársának nevezik Palugyay Zsófiát. ${ }^{8}$ Ez azt jelenti tehát, hogy Iványi Béla ${ }^{9}$ adata a helyes, aki szerint Máriássy János csak 1655. március 24-én halt meg, Palugyay Zsófia tehát csak ekkortól lehetett özvegy. A kérdést eldönti a Máriássyak egyik leszármazottja által

\footnotetext{
${ }^{5}$ CEBANI (1635), RMNY 1625, RMNY 1622, RMNY 2232.

${ }^{6}$ SPILENBERGER-DiÓSZEGI (1999: 2).

7 Szó szerint idézem: „P. Zsófia Mariássy János özvegyénej[!] Révay Ferencz által elvett javait az 1647. és 1649. évi országgyülés visszaadatni rendelte. Jegyzet: 1647. 12, 1649: 66. törvénycikk." https://www.arcanum.hu/hu/online-kiadvanyok/Nagyivan-nagyivan-magyarorszag-csaladai-1/kilencedik-kotet-796B/palugyay-csalad-nagy-palugyaies-boda-falvi. Letöltés: 2019. 09. 09.

8 1647. évi CXII. tc. §3. illetve 1649. évi LXVI. tc. https://net.jogtar.hu/ezer-ev-torveny. Letöltés 2019. 09. 06.

${ }^{9}$ IVÁNYI (1917: XXIX-XXX).
} 
Összeállított nemzetségi tábla, ${ }^{10}$ amely szerint Máriássy János 1593-ban született Batizfalván és Pozsonyban hunyt el 1655. március 24-én. Felesége, nagypalugyai és bodafalvi Palugyay Zsófia pedig 1619-ben született és 1674-ben hunyt el. ${ }^{11}$

A férj, Máriássy János, márkusfalvi Máriássy András és Görgey Margit hét gyermeke közül ötödikként látta meg a napvilágot. Iványi Béla szerint János a batizfalvi iskolába járt, majd Lőcsén Elias Ursinus tanítványa volt, végül a pataki főiskolán fejezte be tanulmányait. A férfi ezután Thurzó Imre udvarában szolgált annak 1621-ben hirtelen bekövetkezett haláláig, majd pedig Nádasdy Pál gróf udvaronca volt két évig. ${ }^{12}$ János nem határozta el túl korán magát a nősülésre, hiszen az életrajzi adatok szerint negyvenkét évesen vette el akkor csupán tizenhat éves menyasszonyát. Máriássy kései házasságának oka lehetett az is, hogy édesapja már 1608-ban elhunyt, neki pedig harmadik fiúként gondoskodnia kellett saját előmeneteléről, hogy életvitelét megalapozhassa. János házassága annak fényében különösen késeinek mondható, hogy 1635-re már legfiatalabb testvére, Máriássy András is második házasságában élt. András ugyanis először ismeretlen dátumtól Kalotay Judit hitvese volt,13 majd annak halála után már 1628-ban feleségül vette a megözvegyült (Papné) Korláth Juditot, mint erről a számukra írt epithalamium is tanúskodik. ${ }^{14}$

Samuel Spillenberger a nászének végén úgy írja alá a müvet, mint Máriássy János keresztapja, de a harmincas számot kifejező XXX után néhány karakternyi hely ki van hagyva a nyomtatványban, ami azt jelenti, hogy talán maga sem emlékezett pontosan, hány évvel korábban keresztelték a fiút. Ha adataink helyesek, akkor a római hetes számnak kellett volna a kihagyott helyre kerülnie: Samuel Ludimontanus M.D. Generosi Dn. Sponsi ante annos XXX [több szóköznyi hely kihagyva] ex. SS. Baptismate Susceptor. Nem világos azonban, hogy itt csak lelki ke-

\footnotetext{
${ }^{10}$ MÁRIÁSSY (2006). A kötet megjelent magyarul is, de nem jutottam hozzá: Máriássy Péter, A Máriássy nemzetség tíz évszázada, Harlequin, Kassa, 2007.

${ }^{11}$ MÁRIÁSSY (2006: 89).

12 IVÁNYI (1917: XXX).

${ }^{13}$ MÁRIÁSSY (2006: 21).

${ }^{14}$ RMNY 1411.
} 
resztapaságról van-e szó, vagy Spillenberger tényleg jelen volt az eseményen, életrajzírója szerint ugyanis 1593-ban Spillenberger már Gölnitzben, illetve szeptembertől Wittenbergben folytatta tanulmányait. ${ }^{15}$

A Máriássy család hosszú történetét egy ősgaléria is megörökíti, amelynek darabjai a világ különböző pontjaira szóródtak szét, de amelyet 2019-ben legalább virtuálisan újra összegyüjtöttek egy albumban. Ebben a kiadványban a Máriássy-Palugyay házaspár egyik tagja sem szerepel. ${ }^{16}$

\section{A bigámista keresztes lovag}

Samuel Spillenberger költeménye tizenegy soros bevezetővel indul, amelyben a szerzői én Múzsáját hívja segítségül, hogy illően köszönthesse a Palugyay törzsökből való menyasszony és vőlegénye, János menyegzőjét. Ezt követően három költemény következik, amelyeket Spillenberger a vőlegény három, már házas fivérének nevében írt. Először János György nevü bátyja mond el egy mesét (narrabo ... fabulam) arról, hogyan születik a rossz feleséggé váló leány. Ezután a vőlegény András nevü öccse mondja el a kétfeleséges gróf történeti hitelü (sequitur bona ... mulier, historica condecoranda fide) esetét. Végül a család aktuális feje, Máriássy Ferenc szepesi alispán élcelődik a derekát nehezen beadó újasszonyon, aki gyorsan megtanulta élvezni a nászéjszakát. Amint a költemény címe mutatja, Spillenberger célja a lakodalmon megjelent vendégek szórakoztatása volt (pro exhilarandis dominis hospitibus nuptiarum), a munka latin nyelve és a benne tárgyalt sikamlós témák miatt azonban az főként a férfi társaság fantáziáját mozgathatta meg.

A második költemény nyomtatott széljegyzete szerint egy bizonyos Wilhelmus de Gleichen thüringiai gróf 1190-ben lejátszódott történetét meséli el. A gróf a Szentföldön a törökök fogságába esett, és rabszolgamunkára fogták, magaviselete és csinos arca miatt azonban beleszeretett a szultán leánya. A szövegben csak török királylányként emlegetett hölgy felajánlotta a grófnak, hogy kiszabadítja, ha cserébe feleségül veszi és magával viszi hazájába. A gróf pironkodva tiltakozott ugyan, hi-

\footnotetext{
15 SPILENBERGER-DiÓSZEGI (1999: 2).

16 TÜSKÉS-MÁRIÁSSY (2019).
} 
szen otthon feleség és két gyermek várta, a keresztény hit pedig tiltja a többnejüséget, de a királylány saját mohamedán hitét tartva mérvadónak, nem látott problémát abban, hogy a gróf más(od)ik felesége legyen. A szökés megtörtént, ám Európába érve a gróf megtudta, hogy első felesége és gyermekei még életben vannak, így rögtön Rómába sietett a pápához, hogy a többnejüség miatt felmentést kérjen, arra hivatkozva, hogy nem a szexuális vágy, csupán a testi-lelki szabadság megszerzésének egyetlen útja vette rá, hogy még első felesége életében a török királylánynak is esküt tegyen. A pápa megadta a felmentést, így a gróf hazatérhetett Thüringiába, ahol a grófné mindkettejüket kitörő örömmel fogadta és illendően megvendégelte. Életük hátra lévő részében ugyan hárman osztoztak a hitvesi ágyon, de a török királylány gyermektelen maradt, így a ház úrnőjének kijáró elsőséget az első feleségnek hagyta meg, ő pedig saját akaratából mintegy szolgálólányként élt a házban.

A Dekameron lapjaira illő történet gyökereit és elterjedését nagyjából a Spillenberger munkáját megelőző évtizedig Mark Riley tárta fel, aki elkészítette Friedrich Hermann Flayder birodalmi koszorús költő 1625ben készült Ludovicus bigamus című komédiájának hypertext kritikai kiadását. ${ }^{17}$ Flayder komédiáját a tübingeni egyetem diákjai mutatták be, amelynek témája akkorra már kb. nyolcvan éve jelen volt az írott forrásokban. Riley rekonstrukciója szerint a történet eredetileg a XIV. században bukkant fel Franciaországban a ma is létező Trazegnies in Hainaut család (Belgium) őseihez kapcsolódva. Valamilyen módon azonban a német területeken a thüringiai Gleichen grófjának alakjához tapadt a legenda, és már az ő példájára hivatkozott a Nagylelkű (der Großmütige) melléknevű I. Fülöp hesseni tartománygróf, amikor az 1530-as években Lutherhez és a reformáció többi vezetőjéhez fordult, hogy első feleségétől elválhasson. 1560 és 1614 között azután legalább nyolc verzióban megjelent Gleichen grófjának története nyomtatásban is. A XVII. század végén Wilhelm Ernst Tentzel, Monatliche Unterredungen ... címü munkája ${ }^{18}$ pedig már 12 olyan kiadványt regisztrál Erfurt történetétől kezdve anekdotagyüjteményeken át teológiai értekezésekig, amelyekben a bigámista grófról olvashattak.

\footnotetext{
17 RILEY (2017) http://www.philological.bham.ac.uk/ludbig/.

18 TENTZEL (1696: 603-610).
} 
Ha Samuel Spillenberger költeményének ihletőjét keressük, abból a két adatból érdemes kiindulnunk, hogy nála Gleichen grófja a Wilhelmus nevet viseli, és hogy az 1190-es dátumot jelöli meg a történet idejeként; semmi egyéb mozzanatban nem térnek el ugyanis a történet verziói annyira egymástól, hogy az filológiailag relevánsnak mondható lenne. Sajnos azonban a fellelhető források egyike sem mutat teljes egyezést a fenti adatokkal. Az általam olvasott kiadványok többségében ugyanis, akár latin, akár német nyelven írták őket, a grófnak nincsen neve, csak úgy emlegetik, mint Comes de Gleichen vagy der Graf von Gleichen. ${ }^{19}$ Johannes Jacobus Manlius, Locorum communium collectanea címü 1568-as kötetében ${ }^{20}$ a tartalomjegyzékben az Adalbertus vagyis Béla nevet adják a férfinak: Albertus Landgravius thuringiae adulter p. 312. A főszövegben azonban Manlius is csak „Quidam Comes de Gleichen” megjelöléssel kezdi mesélni a kétszer házasuló lovag történetét, de időpontot nem jelöl meg. Manlius kötetében számos magyar vonatkozású rész mellett még két „landgravius” rangú férfiról találunk anekdotát: Ludovicus Landgravius története a 703. oldalon olvasható, a Wilhelmi Landgravi prudentia címü elbeszélés pedig a 433. oldalon kezdődik. Esetleg elképzelhető lenne, hogy Samuel Spillenberger egy hasonló kiadványt olvasott, s a több különböző nevü landgravius rangú személy közül a Wilhelmus nevű ragadt meg az emlékezetében? Az a furcsa ugyanis, hogy Mark Riley és elődei kutatásai szerint a Wilhelmus nevet nem társították Gleichen grófjának alakjához, mivel a hagyomány szerint az Ernst, Ludwig vagy Eberwein neveken szerepel a különböző változatokban. A Ludwig, vagyis latinul Ludovicus a gróf bevett neve Erfurt történetírói számára (erről alább még lesz szó), s a fent említett Flayder komédiája is a hagyománynak ehhez az ágához kapcsolható.

A Spillenberger által említett 1190-es év pedig lehet egy visszakövetkeztetés a részéről, ha olyan forrást olvasott, mint például Matthaeus Dresser Rhetorica Inventionis et Dispositionis (Lipcse, 1580) címü müve, amelyben elhangzanak utalások konkrét történelmi személyekre, I. Bar-

19 HONDORF (1568: 257-258), DRESSER (1580: 85-88), MELANDER (1604: 502-503), MEISNER (1611: 642-643), MEIGER (1649: 712-713).

${ }^{20}$ MANLIUS (1568). 
barossa Frigyes császárra, Thüringiai Lajosra és Árpád-házi Szent Erzsébetre. Idézem Dressert:21

Narratio historiae de bigamo comite a Gleichen, cuius monumentum Erphordiae in templo divi Petri extat.

Cum circiter annum Christi millesimum ducentesimum vigesimum septimum Fridericus primus, cognomento Barbarossa, expeditionem in Asiam suscepisset, assecutus est eum Turingiae Landgravius Ludovicus, cui diva Elisabetha, Ungariae regina, uxor erat, et in Sicilia copias suas comitibus, baronibus, nobilibus, et aliis lectissimis viris praestantes, cum illius exercitu coniunxit. Hinc digressus cum eo Brundisium, morbo repentino correptus est: cumque aliquandiu valetudinis causa illic commoraretur, abeunte Imperatore cum exercitu, secutus est comes Turingiae a Gleichen, relicto Landgravio, qui non multo post in die natali Mariae Brundisii expiravit. Fuit autem in hoc comite Turingo animi quaedam celsitas, et ardor pugnandi contra communis nominis Christiani hostes, laude dignissimus. Quocirca cum in recuperatione terrae sanctae quodam die longius e Caesaris castris progressus esset, nimia scilicet pugnae aviditate incensus, hostium multitudine circumfusus est, et a Sarracenico quodam barone captus. Inde crudeliter ab hostibus tractatus, vel in carcere detentus est, vel ad serviles durosque agri colendi labores detrusus. Evenit autem divino quodam beneficio, ut in eum favor cuiusdam mulieris Sarracenicae inclinarit, quae et sua liberalitate eum nonnihil iuvit, et triste servitutis iugum suo colloquio lenivit, mota haud dubie insigni viri virtute. Cumque nobilitatem eius a parentibus acceptam cognovisset, maritum eum sibi expetere coepit. Quanquam vero, ita ut erat, diceret comes, se domo exeuntem legitimam reliquisse coniugem: tantum tamen valuit honesti amoris vis in ista muliere erga comitem, et recuperandae libertatis cupiditas in comite, ut matrimonium cum ea pacisceretur, praesertim cum alia expediendae salutis ratio nulla videretur. Quis autem non miretur tantam in muliere animi magnitudinem, ut quamvis pericula multa et difficultates plurimas sibi propositas sciret, maluerit tamen comitem in terram prorsus ignotam sequi itinere longinquo et molestiis pleno, quam in patria tuto in parentum cognatorumque complexu vivere?

${ }^{21}$ DRESSER (1580: 85-88). 
Ingressi igitur sunt iter, Deo occasionem praebente et cum in Christianorum terram venissent, re omni, ut gesta erat, indicata, a Pontifice Romano veniam bigamiae comes est consecutus. Inde in Turingiam patriam tandem veniens, solus primum ingressus est domum, et ab uxore agnitus et exceptus ardentissime, coepit narrare quomodo fortuna secum, dum abfuisset, egerit: et tandem etiam uxorem aliam Sarracenicam se adducere dixit, quae vitae suae unica assertrix, et reditus in patriam causa extiterit: rogans modis omnibus, ut si se salvum et incolumem ex tanta tamque immani servitute, qua in terra hostili oppressus fuisset, libenter ferat, etiam Sarracenicae coniugis societatem benigne admittat. Quod cum futurum promisisset uxor facilis, et in gratiam mariti, quo multo tempore caruerat, quidvis facere parata, in domum introducta est mulier Sarracenica, et accepta honorifice. Neque compertum est, quod mirum non immerito videtur, ullo unquam tempore dissensionem aut rixam acerbam inter has coniuges extitisse: sed concordia suavi marito uni, in unis aedibus et lecto uno cohabitarunt. Cumque forma antecelleret Sarracenica, admirabili bonitate Dei factum est, ut altera prolis foecunditate praestaret, quo id quod deesset formae, dono liberorum pensaretur. Monumentum extat Erphordiae in aede divi Petri, ubi comes bigamus cum utrinque collocatis uxoribus in lapide magno excisus est. Visus est etiam a multis lectus horum trium coniugum apud comites de Gleichen, qui testes huius narrationis esse possunt.

I. Barbarossa Frigyes ugyanis 1190-ben hunyt el, s ha Spillenberger (vagy a forrása) őt tekintette biztos pontnak a történetben, akkor feltételezhette, hogy a gróf Frigyes császárral indult el a III. keresztes hadjáratba, s a története ennek az eseménysornak egy leágazása. Csakhogy Dresser verziójában, mint fent olvasható, a megjelölt évszám 1227, ami pedig Thüringiai Lajos halálának éve, ám az nem a III., hanem a VI. keresztes hadjárat során következett be, azt a hadjáratot pedig nem Barbarossa I. Frigyes, hanem II. Frigyes Szicília királya vezette. Valójában tehát a két Frigyes összekeverése miatt már Dresser szövege tartalmaz egy kronológiai ellentmondást, s csak feltételezhető, hogy ennek folyománya lenne valahogyan Spillenbergernél az 1190. év emlegetése.

A Spillenberger szövege által felvetett filológiai problémák természete tehát kettős. Egyrészt a történet elmondása lényegi elemeiben megegyezik a fellelhető latin és német nyelvű forrásokkal, de nélkülöz 
olyan specifikus adatokat, mint például a Manliusnál olvasható állítás, ${ }^{22}$ mely szerint a trió közös sírhelye századokig fellelhető volt Erfurtban, és a gyermektelen török királylányt koronával és ruhában, míg a termékeny grófnét meztelenül, rá csimpaszkodó gyermekeivel ábrázolták volna a szarkofágon. Másrészt a gróf nevére és az események idejére vonatkozó adatok Spillenberger szövegében túl specifikusak, és nem sikerült olyan forrást találni, ami akár külön-külön, akár együtt tartalmazta volna őket.

\section{Történeti valóság és a hagyomány továbbélése}

A történeti kutatás nagyjából eldöntöttnek tartja, hogy a bigámista kereszteslovag III. Ernst Gleichen grófja volt (1160-1246), akinek a korban szokatlanul hosszú életébe egyebek mellett két feleség is belefért, s akikkel közös állítólagos síremléke az erfurti Szent Péter templomból 1813ban került át az erfurti dómba. Csakhogy a kutatások szerint a síremlék nem III. Ernst grófot, hanem II. Lambert (1160-1227) gleicheni grófot és két egymást követő feleségét ábrázolja, ahhoz hasonlóan, ahogy az uppsalai dómban I. Gusztáv svéd király síremlékén is megtalálható a király három felesége közül kettőnek az alakja, mintha közös ágyban feküdnének. ${ }^{23}$ A legenda mindenesetre olyan mélyen élt az erfurtiak emlékezetben, hogy a XIX. századi historizmus jegyében a városháza folyosóját hat nagyméretü festménnyel díszítették, amelyek Gleichen grófjának kalandját örökítik meg a kor neves festője, Eduard Kaempffer felfogásában. Addigra már a történet hiányzó részeit is kipótolta a hagyomány, mind a német grófné, mind a török királylány kapott saját nevet, akik így Ottilia és Melechsala néven kerültek rá festményekre és képeslapokra, amelyek teljes digitális gyüjteménye elérhető a Goethe Zeit weboldalon. ${ }^{24}$ A XIX. században a történetnek egy jóval hosszabb válto-

\footnotetext{
${ }^{22}$ Horum monumentum adhuc hodiae Erfurdiae extat, in quo ex utroque latere uxores Comiti astant: altera regina marmorea corona onorata: Comitissa sculpta est nuda, et infantes iuxta pedes eius reptantes. MANLIUS (1568: 312).

${ }^{23}$ A többször nősült magyarországi nemeseknek is fejtörést okozott, hogy melyik házastársuk mellé temetkezzenek, de ilyen több feleséget is befogadó sírhelyről nincs tudomásunk: PÉTER (2008: 51).

${ }^{24} \mathrm{http}$ //www.goethezeitportal.de/wissen/illustrationen/legenden-maerchen-und-sagenmotive/ graf-von-gleichen.html Letöltés: 2019. 09. 06.
} 
zata ponyvanyomtatványként bekerült a magyar köztudatba is, Bucsánszky Alajos pesti kiadója 1873-ban jelentette meg a negyedrét méretben mintegy hetven oldalra rúgó kiadványt, melynek fordítója ismeretlen. ${ }^{25} \mathrm{~A}$ szerint az elbeszélés szerint Melechsala egy német rabszolganő dajkájától tanulja meg érteni és értékelni az európai kultúrát, s az iszlám vallásba beavató nevelése révén a keresztény teológiára is nyitott lett, s amikor Rómában Ernst gróf a pápai diszpenzációért folyamodott, a királylány megkeresztelkedve az Angelika nevet vette fel. E számos mellékszállal színesített változat forrásának feltárása azonban már a folklorisztika és a germanisztika területére tartozik, nem lehet tárgya a jelen dolgozatnak.

\section{Interpretációk és a hazai kontextus}

A legutóbbi interpretációk a kolonializmus jegyében értelmezik a történet kitartó európai, illetve erfurti jelenlétét, az iszlám többnejüségnek a keresztény Európa számára tiltott és lenézett, ugyanakkor vonzó jellegét hangsúlyozva benne. ${ }^{26}$

Mint fentebb említettem, Samuel Spillenberger szövegének e motívumát a másik két, friss asszonyokkal kapcsolatos történet kontextusában a násznép férfitagjainak a vőlegény rovására elsütött tréfái közé sorolnám, a lakodalmi alkalom mint liminális helyzet és az ehhez kapcsolódó, társadalmilag megengedett transzgresszió egyik megnyilvánulási formájaként tekintek rá. A szövegek mélyebb mondanivalója a házasságban esetlegesen kialakuló helyzetekbe való beavatás a férfitársak részéről, és egyúttal a friss házas férfi félelmeinek (rossz feleség, szexuális nehézségek) kimondása és humor általi feloldása. A bigámia mint eshetőség természetesen nem állt fenn a szigorú erkölcsű evangélikus közösségek tagjai számára sem, a többszöri házasodás esélye, illetve kényszere az előző hitves(ek) elvesztése miatt azonban nagyon is része volt a XVII. századi ember valóságának. Az RMNY kötetei számos olyan nászének-gyüjteményt tartalmaznak, amelyek valamelyik házasulandó félnek már a második, harmadik, sőt esetenként negyedik házasságára ké-

25 Melechsala, a szép szaraczén-leány: vagy A tántoríthatatlan szerelem, Pest, Bucsánszky Alajos, 1873. OSZK Kisnyomtatványtár, Pny 436.

${ }^{26}$ MALIK (2012). 
szültek ${ }^{27}$ - a házastárs korai elvesztése tehát legalább tudat alatti félelemként jelen lehetett egy mégoly látványos külsőségekkel megült ünnepségen is, amilyennek a magyarországi nemesi lakodalmakat ismerjük. Mint a tanulmány elején bemutatott életrajzi adatokból láttuk, Máriássy János csupán egyszer házasodott, és nála huszonhat évvel fiatalabb arája tizenkilenc évvel túl is élte őt. Húsz évig tartó házasságukból hat gyermek született. ${ }^{28}$

Bár Spillenberger elbeszélésében is szerepel, hogy Gleichen grófja a pápához fordult diszpenzációért, hogy a török királylánynak tett ígéretét legálisan is megtarthassa, ez a mozzanat mégsem adott okot a lőcsei orvosnak, hogy a vers keretein belül a pápaságnak a házassággal és újraházasodással kapcsolatos felfogását vitatni kezdje. Szakmájából adódóan nem is érezhette feladatának a doktor, hogy ilyen teológiai kérdéseket tárgyaljon, jóllehet a lelkészi tisztséget betöltő kortársai között többen akadtak, akik lakodalmi költeményeikben is alkalmat találtak rá, hogy az újraházasodás mellett és a cölibátus katolikus tantétele ellen érveljenek. Ilyen, a papi nőtlenséget kritizáló verset találhatunk például a selmecbányai evangélikus főesperes, Godfried Titius második házasságára írt gyüjteményben, ${ }^{29}$ és egy prózai betétet a lőcsei lelkész, Christian Schlegel második házasságára kiadott nyomtatványban, ${ }^{30}$ amely a tridenti zsinat vonatkozó törvénycikkét szó szerint is citálja, mint Isten akaratával ellentétes rendelkezést.

Ezek a szövegek azon kevesek közé tartoznak, amelyek a biblikus müveltségi elemeken és a klasszikus antikvitás szövegein kívüli olvasmányokat cím és szerző szerint idéznek fel a magyarországi neolatin nászének költészetben. Eddigi vizsgálataim során csupán két olyan további epithalamium-gyüjteményt találtam, amelyekben teológiai (szak)irodalomnak tekintheto, illetve a laikus olvasmányélményekre

\footnotetext{
${ }^{27}$ A 17. századi epithalamiumok családtörténeti vonatkozásairól szól egy Erdélyi Gabriella és Szabó András Péter szerkesztette Stepfamilies across Religions in East-Central Europe (1500-1800) munkacímű kötetbe készülő angol nyelvü tanulmányom: Ágnes Máté, Seventeenth-Century Patchwork Families in Hungary and the Principality of Transylvania as Reflected by Neo-Latin Wedding Poetry.

${ }^{28}$ MÁRIÁSSY (2006: 25).

${ }^{29}$ RMNY 3444.

${ }^{30}$ RMNY 2232.
} 
reflektáló részek vannak. Az előbbire példa a patikus Christian Seelmann második esküvőjére írt gyüjtemény, ${ }^{31}$ amelyben az egyik verses feladvány (aenigma) megfejtése az Epitstulae Obscurorum Virorum (15151519) c. korai protestáns gyűjtemény egy helyére mutat. A világi, szórakoztató olvasmányra való utalás pedig a fent említett Christian Schlegel és Rosina Gloger esküvőjére készült már idézett gyüjteményben fordul elő, ${ }^{32}$ ahol a menyasszony keresztnevére (Rosa-Rosina) írott vers kapcsán felidézik Achilles Tatius Clitophon és Leucippe címü müvének a rózsáról szóló passzusát:

Apud Achillem Tatium, lib. 2. De Leucippe et Clitophonte, invenitur sequens encomium rosae, ex oda quadam in prosaicam orationem dissolutum. Existimatur autem oda illa Sapphus esse. Si floribus vellet Jupiter imponere regem, rosa inter flores regnum obtineret. Terrae est ornamentum, plantarum decus, oculus florum, prati rubor, pulchritudo coruscans etc.

Mint ismeretes, Clitophon és Leucippe története a 16. század végén már magyar fordításban is olvasható volt, ${ }^{33}$ de a történet ismertségére Balassi Bálint 30., Mire most barátom incipitü, csonkán fennmaradt versén kívül alig van adat. A magyarországi neolatin nászénekekből feltáruló müveltséganyag részletes áttekintésére itt nem kerülhet sor, annak külön fejeztet szánok a témából írott készülő monográfiámban.

\section{Összegzés}

Samuel Spillenberger 1635-ös latin nászéneke amellett, hogy igen szórakoztató szöveg, a magyarországi neolatin költészet témáinak széles forrásvidékére hívja fel a figyelmet. A költemény azt a feladatot állítja a kutatás elé, hogy a hazai epithalamiumok szövegeiben szabályszerüen megjelenő bibliai és klasszikus műveltségi elemek mellett figyelmet fordítson a világi és modern olvasmányanyag jelenlétére és elkezdje ezek szisztematikus feltárását is. A művelődés- és olvasmánytörténeti kutatások ugyanis mára világosan bizonyították, hogy a magyarországi mü-

\footnotetext{
${ }^{31}$ RMNY 3012.

32 RMNY 2232.

33 ORLOVSZKY (2004: 339-357).
} 
veltség megismeréséhez nem ad kellő tájékoztatást, ha csak azokat a szövegeket listázzuk, amelyeket magyarra is lefordítottak, és az egykori könyvjegyzékek tanúságtétele is csak részleges információkat nyújt számunkra. Ezért elengedhetetlenül fontos, hogy a latinul és a magyarul megjelent hazai munkákban témától függetlenül figyeljük és a modern kiadásokban jelezzük ezeknek az adott témakörben talán anomáliának tünő, de müvelődéstörténeti szempontból tanulságos adatoknak a felbukkanását.

Carmen joco-serium polymetron. Pro exhilarandis dominis hospitibus nuptiarum Generosi Domini Ioannis Mariasi de Markusfalva Sponsi etc.

Surge gravi vel treis annos mea Musa veterno Torpida! Nobilibus dic carmen nobile Sponsis,

Sive meo sive alterius sub nomine fusum.

Surculus ex celebri Mariasidos arbore, turgens

Progenie simili, Generosa ex stirpe PALUDIAI

Plantulam, in aeternum foedus geniale JOHANNES

Suscipit: a teneris Musarum is cultor, ut inde

Musarum quoque sit sacro dignissimus hymno.

Ergo agite o vos tres simili sub foedere, Fratres

Germani! vestro quatuor de Fratribus uni

Ludite, votaque fundendo, venereisque canendo

GEN. DN. GEORGIUS MARIASI etc.

Salvete praeclara Hospitis HOSPITES!

Narrabo textam carmine fabulam,

De Uxore prava, cum Marito

Belliferum capiente somnum.

In somnio vidit Pater, acriter

Se examinare ex Grammate filium,

Ut diceret pro parte, cujus

Sit generis mulier? Resolvit

Se sic: inter quae Nomina desinunt, Quod masculini sunt generis. Pater

Commotus ira, Conjugi mox 
Dat colaphum, puerum putando.

Res digna risu. Haec nacta alapa[?] statim

Ceu vipera assurgit, furibunda, trux,

Clamore magno dormientem

Excitat et volat in cubitus:

Crudeliter tacto miserum excitando

Utriusque pegnes[?] tergora vervitat

Hinc prodiit nuper lili...[?]

Ille, MALUS MULIER vocatus

Haec profero non ut facinus probam

Sed ut probam qui ducere Conjugem

Vult, oret, atque ante eligat, quam

Diligit. hoc Juvenes notate!

Jam care Frater! Quid voveam tibi

Sponso? Nihil quam ex pectore Conjugem

Virtutibus cultam suorum a

Sanguine Nobilium Parentum.

GEN. DN. ANDREAS MARIASI etc.

Iam mala praecessit, sequitur bona, rara Marito

Mullier[!], historica condecoranda fide. ${ }^{34}$

Germanus Comes in diro discrimine belli

A Turcis captus ducitur in Thraciam.

Compedibus junctum duris ubi conspicit alma

Virgo, (Mahometi filia Regis erat)

Moribus acceptum Comitem faciemque venustum

Deperit, occulte talia verba ferens:

Servitiis pressum duris, captive, miserta

Tis, ${ }^{35}$ ego te proprio solvere Marte queo,

Te mihi si vinclo cupis associare jugali,

Inque tuam tecum ducere vis Patriam.

Captivus rosco suffusus forte rubore, ac

Pulcrior hinc faciem conspiciendus, ait:

Non licet, est mihi namque domi dulcissima conjunx,

\footnotetext{
${ }^{34}$ A bal margón: Comes Wilhelmus de Gleichen, in Thuringia. Anno 1190.

${ }^{35}$ A jobb margón: tui vel tis mei vel mis pronom.
} 
Sunt pariter thalami pignora cara duo.

Illa, quid impediat, respondit, habere duas, treis

Aut plureis, licet hic sicut habere Thraces.

Ille modo Libertatis compulsus, et hac cum

Virgine Regali vincula tecta subit.

Dimissus liber. Patriam dum reppetit[!], audit

Vitam cum gnatis quod prior Uxor agit.

Promptus adit Romam, rem gestamque ordine narrat

Pontifice, rata qui vincla secunda facit.

Non quod ad haec Comitem traxisset foeda libido,

Sed grave servitii ac carceris illud onus.

Papali accepto secum diplomate laetus

Conjuge cum Thracica pervenit usque domum.

Astera, conspecto domino cum pellice, Conjunx

Obvia in amplexus facta utriusque ruit.

Flet prae laeticia, repetita dat oscula summa:

Omnia quae hospitibus sunt facienda facit.

Ambas exercet magni reverentia cultus,

Ardenti sibimet semper amore pareis.

Turcica (quod mirum) quantumvis Regia proles,

(Forte quod haec sterilis: sterilis illa fuit),

Pignora Germanae tractando cedit honori,

Vilis et ancillae sponte gerendo vicis.

Adde, quod uni hi tres simul incubuere cubili.

UXORES INTER FABULA RARA DUAS.

Haec valeant. Jam te Frater carissime, Sponsum

Ulnis amplector laetus utrisque meis.

Et precor, ista tuis Conjunx virtutibus apta

Successus tibi sit causa caputque boni.

Pareat et pariat, pereatque quod obstat: amanteis

Quos castos junxti protege Jova Deus!

GEN. DN. FRANCISCUS MARIASI, pro tempore Vice-Comes Comitatus Sepusiensis etc.

Nuper Sponsa fuit, timens cruentum

Primo in concubitu imminere vulnus 
A Sponso sibi, quam manu repellit.

At Sponsus genibus subinde flexis

Admissum rogat, obsecratque frustra:

Quid he[?] ${ }^{36}$ porrigit is manus sinistra

Sponsorem digitum, atque in os rebellis

Imponit bene dentibus premendum.

Vel scintillam ${ }^{37}$ ubi laeserit puellam

Admittit bona supplicem, Virumque a-

gnoscit, non modo nil morata morsum.

Amplexa est humeris utrisque grata

Pro facto: sed et osculata Sponsum,

Congressus simileis veleM[!] peroptans.

Hunc, Frater, lepidum jocum fer, aequo

Ut par est animo. Cupido nulla

Ignoti: decet ut bonas puellas.

Restat seria res: mihi meaque

Quod possum, voveo Tibi Tuaeque

Flammam perpetuam paris favoris;

Vitam Nestoream pii laboris:

Prolem Christicolam tui saporis.

Lusit Samuel Ludimontanus M. D. Generosi Dn.

Sponsi ante annos XXX ex. SS. Baptismate Susceptor.

\section{Felhasznált irodalom}

CEBANI 1635

Syncharma beneprecatorium in solennitatem nuptiarum ... Ioannis Mariasi de Markusfalva sponsi ac ... virginis Sophiae ... Francisci Palugyai de Kis-Palugya filiae suavissimae sponsae, anno $d n$. MDCXXXV die 14. Jan. celebratam ... scriptum ... ab Abrahamo Czebani, iurato inclyti comitatus Scepusien. iam ad annum 25., qui ultimus, notario et aliis quibusdam bonis amicis, Lőcse, Brewer, 1635. Országos Széchényi Könyvtár, RMK II. 502b(cop.). RMNY 1620.

DRESSER 1580 M. DRESSER, Rhetorica Inventionis et Dispositionis, Illustrata et Locupletata quam Plurimis exemplis, Sacris et Philosophicis, Leipzig, 1580.

\footnotetext{
${ }^{36}$ A dőlt betűkel nyomtatott részekről helyenként alig látható a fénymásolat.

37 Teljesen bizonytalan olvasat, halvány a másolat.
} 
HONDORF 1568

IVÁNYI 1917

MALIK 2012

MÁRIÁSSY 2006

MELANDER et al. 1604 O. Melander, D. MElAnder, J. DRYMELDiUs, Jocorum atque seriorum tum novorum tum selectorum atque memorabilium liber primus, jucundus, utilis, lectuque maximopere dignus, Lichae, 1604.

MEIGER 1649

MEISNER 1611

ORLOVSZKY 2004

PÉTER 2008

RILEY 2017

RMNY 1110

RMNY 1411

RMNY 1622

A. HONDORF, Promptuarium Exemplorum. Historienn ond Exempel buch: Aus Heiliger Schrifft, und vielen andern bewerten und beglaubten Geistlichen und Weltlichen Büchern und Schrifften gezogen, Leipzig, 1568.

IVÁNYI B., A márkusfalvi Máriássy család levéltára 1243-1803, Lőcse, 1917 (Közlemények Szepes Vármegye Múltjából különlenyomat).

J. MALIK, Orientalism and Occidentalism. The Case of Earl of Gleichen, Islamic Studies, 51/2 (2012), 119-137.

P. MÁRIÁSSY, X storočí rodu Máriássy, Harlequin, Košice, 2006.

S. MEIGER, Nucleus historiarum, Ulm, 1649.

B. MeISNer, Philosophia Sobria, Hoc Est: Pia Consideratio Quaestionum Philosophicarum, In Controversiis Theologicis, quas Calviniani moverunt Orthodoxis, subinde occurrentium, Raab, 1611.

Régi Magyar Költók Tára. XVI. századbeli magyar költók müvei. Új folyam. Illyefalvi István, Cserényi Mihály, Csáktornyai Mátyás, Póli István, Beythe István, Baranyai Decsi János, Ceglédi Nyíri János, Munkácsi János és Ismeretlen szerzők históriái. Telegdy Kata verses levele, Fortuna sorsvetökönyv, Naptárversek. 1587 - 1600, s. a. r. OrLOvsZKY Géza, Budapest, Balassi Kiadó, 2004.

PÉTER K., Házasság a régi Magyarországon: 16-17. század, Budapest, L'Harmattan, 2008.

Friedrich Hermann Flayder's comedy Ludovicus bigamus (1625), A hypertext critical edition by Mark RILEY, Posted August 10, 2017. http://www.philological.bham.ac.uk/ludbig/

SPILENBERGER-DIÓSZEGI 1999

SPILENBERGER-DiÓSzEGI Gy. A., A Spillenberg család története. Spillenberg Sámuel (1573 - 1654) löcsei orvosdoktor élete; a kassai Spillenberg festőcsalád (befejező közlemény), Turul, 72 (1999), 1-16.

Bellaria poetica. Convivio nuptiali ... Samuelis Spilenberger med. doct. comitatus Scepusien. reipublicaeque Leutschovien. medici ordinarii et ... Magdalenae, ... Mich. Clementis consularis et notarii eiusdem reg. liberaeque civ. Albae Scepusiae ... filiae, sponsorum nuptias celebrantium die 24. Aprilis anno MDCXVI. Exhibita ab amicis, Kassa, Johannes Festo, 1616.

In festivitatem nuptialem ... Andreae Mariasi de Markvsfalva sponsi et ... Ivdithae Korlath ... Georgii Pap, p.m. relictae viduae, sponsae ad 27 Junij anni 1628 Cassoviae celebran. observantiae contestan. ergo gratulantur Johannes Serpilius, eccl. Caismarcen. pastor, m. David Z. Praetorius, sch. Caism. r., Kassa, Daniel Schultz, 1628.

Epithalamia votiva et gratulatoria in celebritatem festivitatis nuptialis clariss. ac doctiss. viri dn. Davidis Froelichii, mathematici celeberrimi ac per Ungariam et potissimas Germaniae partes astronomi practici dexterrimi polyhistoris et philologi laboriosissimi cum lectissima 
RMNY 1625

RMNY 2232

RMNY 3444

TENTZEL 169 pudicissimaque virgine Ivditha prudentis ac honorati viri Bartholomaei Bertrami, senatoris reip. Caismarcensis primarii ac chymici solertissimi filia, eidibus quinctilis, anno MDCXXXV Deo favente obeundam, concinnata ab amicis, Lőcse, Brewer, 1635.

Gamelia votiva et beneprecatoria in solemnitatem nuptiarum ... Iosephi Alaudae, rectoris ac moderatoris scholae Cibinien. ... filii Bartholomaei Alaudae, eccl. Sclavonicae Leutschoviensis pastoris a 35 annis fidelissimi, meritissimi cum Susanna, viri quondam Johannis Lapscheri notarii reipub. Cibiniensis jurati filia derelicta, jam autem Andreae Hertelii, reipub. Cibiniensis consularis ac notarii jurati etc. privigna dilectissima, anno MDCXXXV 7 Nonas Decembr. Obeundam, exorata ab amicis, Lőcse, Brewer, 1635.

Votis, quae praemodum reverendus... vir... Christophorus Schlegelius, ... ecclesiae in... Leutschovia pastor et gymnasii ibidem inspector... iterum sponsus et... virgo Rosina Glogeria, ... Christophori Glogeri, civis et mercatoris in republica Wratislaviensi primarii filia, ... sponsa ad diem 25. Octobr. anno 1648, ritu sane quasi solenni Leutschoviae coniungendi facient, vota sua devota subnectunt amici et clientes, Löcse, Brewer, 1648.

Eulogemata poetica, queis felicibus neogamorum tedis ... Gothofredi Titii, ecclesiae in reg. lib. civit. Mont. Schemnitz. evangel. archidiaconi ... sponsi et ... Euphrosynae, de ... Kaiserorum familia sponsae ..., Michaelis Heydt, urburarii patrii relictae viduae ... Matthaei Rittmulleri, in ordine senatorio primi et urburarii ... haud postremi ... neptis, Christo archigamo praeside ... MDCLXIIX. die X. Januar, bona verba ... collegae, fratres et amici dicunt., Lőcse, Brewer, 1668.

W. E. TENTZEL, Monatliche Unterredungen einiger guter Freunde von allerhand Büchern und andern annehmlichen Geschichten. Der andere Druck von Fehlern gereiniget, Gleditsch, 1696.

TÜSKÉS - MÁRIÁSSY 2019

TÜSKÉS A., MÁRIÁSSY P., A Máriássy család ősgalériája, Budapest, Kalligram, 2019. 